AgnieszKa BrzosKo-SERMAK

Uniwersytet Pedagogiczny, Kraków

\title{
Innowacyjność a endogeniczne zasoby miast wschodniego pogranicza Polski
}

\author{
WPROWADZENIE, CELE BADAŃ
}

Zainteresowanie miastami nadgranicznymi wschodniego pogranicza Polski jest przede wszystkim wynikiem chęci prześledzenia ich sytuacji społeczno-gospodarczej i uwarunkowań rozwoju miast o specyficznym, peryferyjnym położeniu w obrębie województw, które borykają się z wieloma problemami. Z drugiej strony są to ośrodki o ciekawym położeniu geopolitycznym, pełniące ważną rolę w międzynarodowych układach komunikacyjnych Wschód-Zachód.

Ważnym problemem, jak również praktycznym znaczeniem wyników pracy, są także możliwości przyszłego rozwoju badanych miast i wykrycie, czy ich położenie w pobliżu zewnętrznej granicy UE skutkuje wzrostem, czy stagnacją. Zainteresowanie to wynika ze słabnącej roli granic jako barier pomiędzy krajami członkowskimi UE, dzięki czemu dochodzi do dynamicznego rozwoju miast niegdyś nadgranicznych. $Z$ drugiej jednak strony, przenoszenie funkcji zabezpieczania na zewnętrzne granice UE powoduje różne ograniczenia. Wschodnie pogranicze Polski jest szczególnym przypadkiem, gdyż można zaobserwować tam oba opisane przypadki.

Miasta nadgraniczne wschodniego pogranicza Polski mają trudniejsze warunki rozwoju niż inne, nie ograniczone przebiegiem pobliskiej granicy, która z reguły uszczupla zasięg oddziaływania miast nadgranicznych. Interesujące wydaje się przeanalizowanie zaangażowania władz lokalnych oraz mieszkańców w różnego typu inicjatywy mogące pobudzić wewnętrzny rozwój ośrodków. Z tego względu głównym celem pracy było zbadanie wybranych aspektów aktywności endogenicznej i zastanowienie się, czy można zaliczyć je do działań innowacyjnych, oraz czy są one w stanie warunkować lokalny sukces bądź stagnację. Można stwierdzić, że właśnie dzięki silnym i sprawnie działającym lokalnym liderom (Chojnicki 2007), stosującym często innowacyjne działania, stwarza się szansę wykorzystania potencjału badanych ośrodków, co ,[...] może spowodować samopodtrzymywalny rozwój społeczny i gospodarczy" (Sobala-Gwosdz 2005). Rozwój taki jest jednak możliwy jedynie w przypadku, gdy opisane działania zostaną zainicjowane przez lokalne władze lub społeczność. 


\section{ZAŁOŻENIA BADAŃ}

Szczegółowe analizy bazują na prześledzeniu aktywności władz miast nadgranicznych, które oceniono na podstawie:

- strategii rozwoju miast,

- funduszy strukturalnych UE,

badając zaś aktywność lokalnych społeczności autorka wzięła pod uwagę:

- działalność profesjonalną, naukową i techniczną,

- prasę lokalną, wydawców i redakcje,

- fundacje i organizacje społeczne.

Zakres przestrzenny pracy obejmuje Polskę północno-wschodnią i wschodnią, sąsiadującą poprzez granice państwowe z Federacją Rosyjską (Obwód Kaliningradzki), Litwą, Białorusią i Ukrainą. Szczegółowe badania i analizy zostały przeprowadzone dla 28 miast usytuowanych w strefie nadgranicznej (ryc. 1).

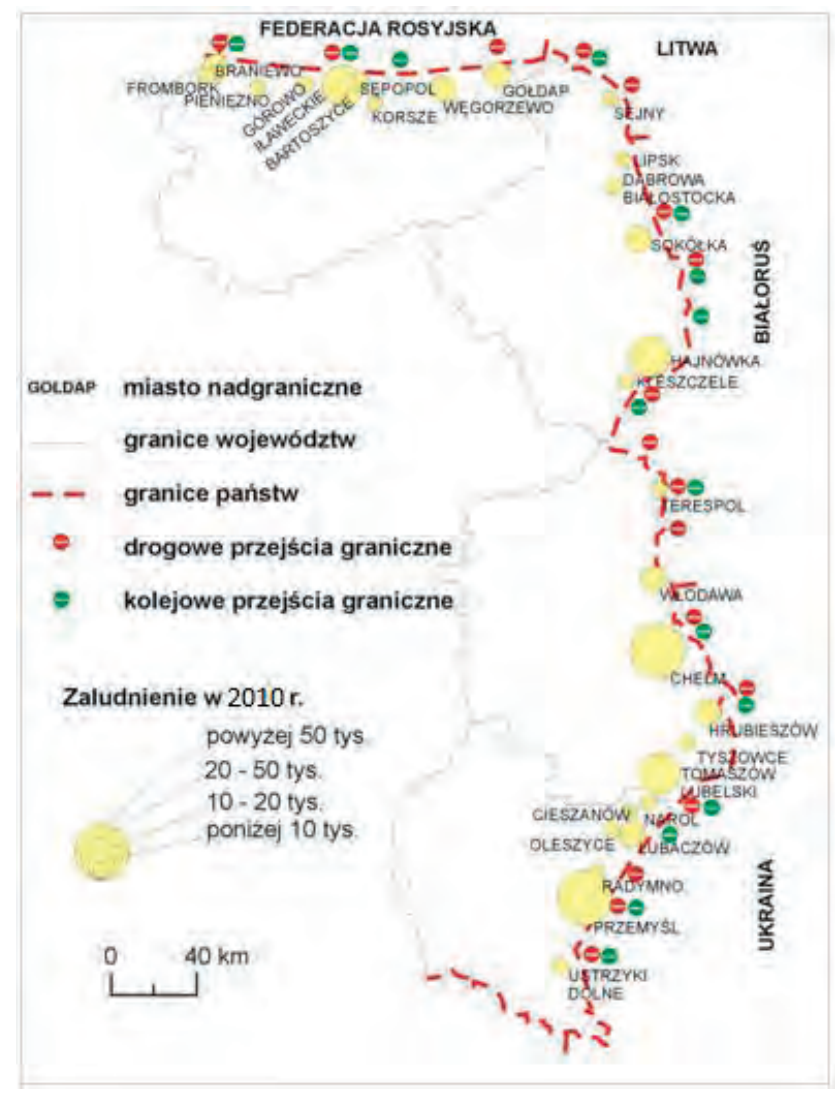

Ryc. 1. Obszar badań

Źródło: Opracowanie własne na podstawie danych Banku Danych Regionalnych GUS 
Zakres czasowy obejmuje statyczne ujęcie bazujące na danych z końca 2010 r. Jedynie w celach porównawczych, bądź dla zobrazowania dynamiki, odwołania dotyczą lat wcześniejszych.

Zebrane dane pochodzą z różnych źródeł. Informacje, które posłużyły do analizowania innowacyjności władz lokalnych i aktywności mieszkańców miast nadgranicznych pochodzą z Urzędów Miast, Gmin oraz Wojewódzkich, jak również z Polskich Książek Telefonicznych i Panoramy Firm oraz Internetu. Natomiast dane odnoszące się do wykorzystania funduszy strukturalnych UE oparto o informacje Ministerstwa Rozwoju Regionalnego. Uzyskano też informacje o liczbie podmiotów gospodarczych wpisanych do rejestru REGON do sekcji M oraz o liczbie fundacji i stowarzyszeń z Banku Danych Lokalnych GUS.

Wykorzystana w niniejszej pracy literatura i materiały niepublikowane dzielą się na kilka grup tematycznych. Pierwsza dotyczy miast nadgranicznych, ich rozwoju, planowania oraz przemian, jakie zachodzą w ich obrębie oraz pomiędzy nimi (Minghi 1963; Passi 2001) jak też bariery rozwojowej, jaką jest pobliska granica (Proniewski 1993; Komornicki 1999). Dodatkowo posłużono się literaturą odnoszącą się do kwestii definicyjnych i terminologicznych użytych w niniejszej pracy (Borowiec, Dorocki, Jenner 2009; Hansen 2001; Knox, Marston 1998; Rachwał, Widermann, Kilar 2009; Zioło 2010). Następna część literatury dotyczy miast jako podmiotu oddziaływań pobliskiej granicy oraz ich rozwoju społeczno-gospodarczego (Proniewski 1993; Misztal 1994; Churski, Krawczyk, Tobolska 1994; Koter 1998; Chojnicki 1999; Komornicki 2003). Istotne było skonfrontowanie otrzymanych wyników z teoriami, w celu wykrycia pewnych wzorów przemian i prawidłowości nimi rządzących. Ważną częścią literatury są studia, opracowania i projekty dotyczące badanych 28 miast nadgranicznych, zwłaszcza odnośnie historii, przemian politycznych i ekonomicznych, jak również transgranicznej współpracy badanych miast. Niezbędną częścią literatury są wreszcie opracowania, projekty i plany przygotowane przez jednostki administracji publicznej badanych miast, mające duży wpływ na rozwój tychże ośrodków.

\section{TERMinOLOGIA}

W niniejszej pracy za granicę państwa przyjmuje się (według Ustawy z dnia 12 października 1990 r. o ochronie granicy państwowej) ,powierzchnię pionową przechodzącą przez linię graniczną, oddzielającą terytorium państwa polskiego od terytoriów innych państw. Granica państwowa rozgranicza również przestrzeń powietrzną, wody i wnętrze Ziemi" (Dz. U. Nr 78, poz. 461, z późn. zm.). Autorka granice traktuje przede wszystkim jako bariery przestrzenne, które w ciągu wielu lat zmieniają funkcje, wpływając przez to na funkcjonowanie obszaru nadgranicznego, a w szczególności na miasta tam usytuowane (Minghi 1963; Passi 2001). Rozróżnia także problemy funkcjonowania granic wewnętrznych UE (jak granica Polski z Litwą), jak również zewnętrznych (pozostałe odcinki granicy północnej i wschodniej - z Rosją, Białorusią i Ukrainą).

Region nadgraniczny lub pograniczny rozumiany jest jako region terytorialny wchodzący w skład danego państwa lub kraju, który poprzez granicę państwową graniczy z innym państwem, a więc położony jest po jednej stronie granicy państwa (Rykiel 1990; Gabbe 1996; Chojnicki 1999). 
W prawodawstwie polskim strefa nadgraniczna obejmuje cały obszar gmin przyległych do granicy państwowej. Jeżeli określona w ten sposób szerokość strefy nadgranicznej nie osiąga $15 \mathrm{~km}$, włącza się do niej również obszar gmin bezpośrednio sąsiadujących z gminami przyległymi do granicy państwowej (Dz. U. Nr 78, poz. 461, z późn. zm.). Ze względu jednak na fakt, że strefa nadgraniczna może osiągać różne szerokości, na potrzeby tej pracy przyjęto, że badane ośrodki nie będą położone dalej niż $20 \mathrm{~km}$ od granicy państwowej, licząc w linii prostej (ryc. 1).

Bazę ekonomiczną miast tworzą funkcje związane z produkcją, przetwarzaniem i handlem dobrami, jak również z zyskami z usług świadczonych na rzecz otoczenia miasta, jego zaplecza, oraz innych miast (Dziewoński 1971). Działalności te, jeżeli prowadzą do gromadzenia kapitału w mieście, nazywane są funkcjami podstawowymi (egzogenicznymi). Pozostałe zaś funkcje (endogeniczne) skierowane na zaspokojenie potrzeb mieszkańców miasta, nie generują zysków od ,zewnętrznych” klientów. Cały ten proces to stały wzrost, będący rezultatem rozwoju gospodarki kraju, efektów mnożnikowych i korzyści skali (Knox, Marston 1998).

Coraz większe znaczenie w rozwoju lokalnym odgrywa praktyczne zastosowanie wiedzy oraz szybkie i sprawne przesyłanie informacji. Podobnie wysoko ceniona jest umiejętność przekształcania istniejących możliwości w nowe idee i wprowadzania ich do praktycznego zastosowania. Powyższe cechy charakteryzują działania o charakterze innowacyjnym, a gospodarka odznaczająca się właśnie tą cechą „decyduje o pozycji konkurencyjnej gospodarek krajowych na globalizującym się rynku międzynarodowym" (Ciok, Dobrowolska-Kaniewska 2009). Procesy innowacyjne gospodarki i układów przestrzennych można rozpatrywać w zależności od różnorodnych celów (Zioło 2010). Niniejsza praca w znacznej mierze będzie odwoływać się do poszukiwania cech innowacyjnych w sferze społecznej oraz instytucjonalnej.

\section{HISTORYCZNE UWARUNKOWANIA PERYFERYJNOŚCI BADANYCH OŚRODKÓW}

Badane miasta charakteryzuje zróżnicowana geneza historyczna, będąca pochodną odmiennych dziejów politycznych (Krzysztofik 2000). Ośrodki te przez kilka stuleci, pomimo zmian przynależności państwowej, rozwijały się w sposób niezakłócony bliskim przebiegiem granicy państwowej, posiadając szeroki obszar oddziaływania (Brzosko-Sermak 2009).

Pierwsze spośród badanych miast powstały w średniowieczu w ramach polityki osadniczej i administracyjnej Zakonu Krzyżackiego. Nie sąsiadowały wówczas z granicą państwa. Ośrodki położone w granicach dzisiejszych województw lubelskiego i podkarpackiego powstawały począwszy od XIV w. Nadgraniczne położenie w pobliżu granicy Polski i Wielkiego Księstwa Litewskiego miały wtedy Włodawa i Hrubieszów. Spośród analizowanych ośrodków najpóźniej powstały te położone obecnie na terenie Podlasia, „większość lokacji przypadła tam na XVI w., a badane miasta nadgraniczne w tym województwie powstawały aż do XVIII w.” (Brzosko-Sermak 2009). W ich przypadku również położenie nie wiązało się wówczas z bliskością granicy państwowej.

Duże znaczenie dla rozwoju badanych miast miało stulecie utraty państwowości: podział Rzeczypospolitej pomiędzy Rosję, Prusy i Austrię i zmiany terytorium Polski w XX w. 
(Eberhardt 2004). Powstały wtedy znaczne dysproporcje gospodarcze i infrastrukturalne między poszczególnymi regionami kraju (Lijewski 1994).

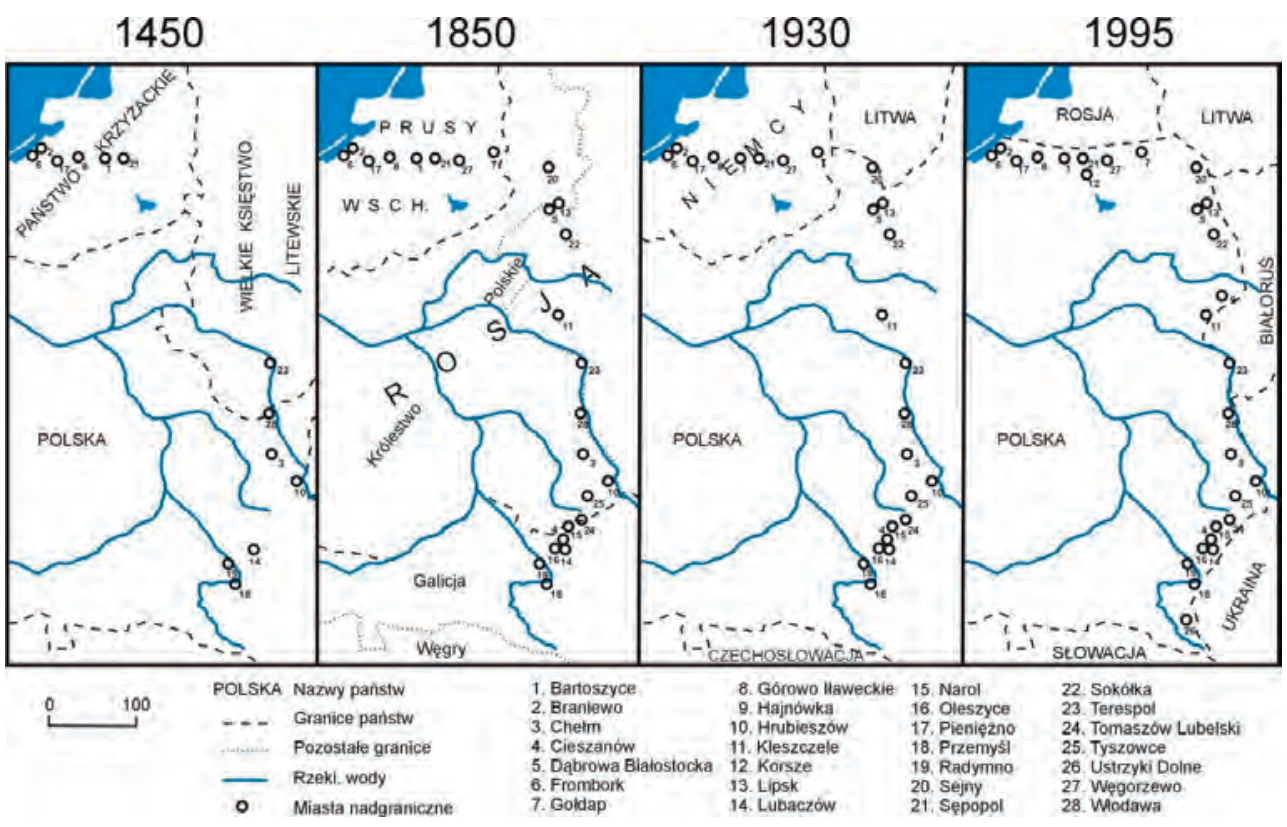

Ryc. 2. Położenie badanych miast na tle granic Polski w latach 1450, 1850, 1930 i 1995

Źródło: A. Brzosko-Sermak 2009, Szczególne cechy rozwoju miast wschodniego pogranicza Polski, [w:] Czlowiek i rolnictwo, red. Z. Górka, A. Zborowski, IGiGP UJ, Kraków, s. 203-212

Podczas gdy w XIX i na początku XX wieku obecne tereny zachodnich i północnych województw Polski przechodziły intensywny rozwój przemysłu, infrastruktury technicznej i nowoczesnych metod gospodarowania w rolnictwie, badane ośrodki bazujące na rolnictwie nie generowały bodźców rozwoju gospodarczego (Ministerstwo Rozwoju Regionalnego 2007). Obecne bardzo wyraźne różnice w poziomie społeczno-gospodarczym wschodnich województw Polski są wynikiem XIX-wiecznego podziału państwowego. Dzisiejsze województwo podkarpackie wchodziło w skład Austro-Węgier, podlaskie i lubelskie - Rosji, zaś warmińsko-mazurskie - Niemiec. „W tamtym czasie istniało już 25 z 28 badanych w tej pracy miast, ale tylko niektóre z nich były w tym czasie ośrodkami nadgranicznymi” (Brzosko-Sermak 2009).

Rozwój badanych ośrodków w okresie międzywojennym charakteryzował się zróżnicowaną polityką gospodarczą Polski i Niemiec. Ta pierwsza inicjowała procesy industrializacyjne, a druga uzyskała w tym czasie stosunkowo wysoki poziom rozwoju infrastruktury.

Po II wojnie światowej wszystkie analizowane miasta zaczęły funkcjonować jako ośrodki nadgraniczne, borykając się z peryferyzacją i uszczuplonymi obszarami oddziaływania (Brzosko-Sermak 2009). Sześć miast spośród badanych nie posiadało wtedy praw miejskich. 
W pierwszych latach transformacji, po 1989 r., badane miasta nie zostały dotknięte niekorzystnymi zmianami strukturalnymi w gospodarce, głównie za sprawą rozwiniętego potencjału przemysłowego. Począwszy jednak od 1992 r. gospodarka tego obszaru nie była w stanie sprostać wyzwaniom gospodarki rynkowej (Ministerstwo Rozwoju Regionalnego 2007). Powyższe uwarunkowania zadecydowały w znacznym stopniu o obecnej kondycji społeczno-gospodarczej regionu wschodniego.

\section{AKTYWNOŚĆ WŁADZ I MIESZKAŃCÓW A INNOWACYJNOŚĆ.}

STRATEGIE ROZWOJU

D. Osborn i T. Gaebler (1992) użyli metafory, że jeżeli lokalni liderzy „będą umieli sterować łodzią, a nie tylko wiosłować”, to takie jednostki lokalne będą miały przewagę (Sobala-Gwosdz 2005) w coraz silniejszej konkurencji między miastami. Jednymi z narzędzi, dzięki którym w przemyślany, świadomy, zaplanowany i długookresowy, a w rezultacie także i skuteczny sposób można zarządzać miastem, są właśnie plan rozwoju lokalnego i strategia rozwoju miasta. Twórcy takich dokumentów muszą przede wszystkim zastanowić się, co należy zrobić, będąc świadomym możliwości i zagrożeń miasta, aby ośrodek ten mógł funkcjonować i rozwijać się w przyszłości. Ważne jest również zwiększenie zdolności adaptacyjnych miasta w zmieniającym się świecie (Rzeszowska Agencja Rozwoju Regionalnego 2000) poprzez wprowadzanie działań o charakterze innowacyjnym.

Autorka przeanalizowała strategie rozwoju oraz plany rozwoju miast wschodniego pogranicza Polski pod kątem informacji związanych z ich położeniem nadgranicznym i działaniami innowacyjnymi. W wielu przypadkach analizowane materiały zostały opracowane jako łączny dokument dotyczący miasta i gminy. Opracowania te były zróżnicowane pod względem zawartych w nich informacji, ich szczegółowości oraz konkretności przedstawianych celów rozwoju miast. W dwóch przypadkach - Hrubieszowa i Tyszowiec, autorka nie odnalazła bezpośrednich odwołań do szans i zagrożeń rozwoju, ani do planowanych działań w kontekście nadgranicznego położenia miasta.

Głównymi tematami badań były szanse, zagrożenia oraz główne cele strategiczne rozwoju miast bezpośrednio związane z nadgranicznym położeniem. Z przeprowadzonej przez autorkę analizy wynika, że 13 ośrodków rozważa swoje położenie i wiążącą się z nim bliskość granicy państwowej jako jedną z podstawowych szans rozwoju. Taka sama opinia związana jest w 10 miastach ze współpracą transgraniczną. W dwóch miastach zostały wyartykułowane pewne zastrzeżenia co do bezpośredniego wiązania położenia nadgranicznego z potencjalnymi szansami, np. przyszłego przeniesienia zewnętrznej granicy UE dalej na wschód (włączenia Ukrainy do UE) lub pod warunkiem otwarcia nowego przejścia granicznego. Stwierdzenia takie zwracają uwagę na fakt, iż bez bliskości przejścia granicznego oraz dobrej komunikacji z nim miasta nadgraniczne skazane są na pogłębiającą się izolację.

Położenie nadgraniczne pojawiało się również jako zagrożenie dla rozwoju aż czternastu miast wschodniego pogranicza Polski. Zastanawiające jest jednak, że w zdecydowanej większości są to te same miasta, które swoje położenie określiły w kategoriach szans.

Analiza celów strategicznych rozwoju miast nadgranicznych wykazała, że 18 miast wiązało je bezpośrednio z nadgranicznym położeniem. Autorka stwierdziła jednak, że w obrębie 
tego celu, lub też podczas omawiania innych, nawiązywanie do pobliskiej granicy państwowej było dość częste i dotyczyło wielu aspektów funkcjonowania ośrodków. Niewiele jednak było zapisów dotyczących działań o charakterze innowacyjnym. Jedynie największe spośród badanych miast odnosiły się do tego typu kwestii przede wszystkim poprzez nawiązanie do posiadanej już bazy naukowej.

Z powyższej analizy wynika, że większość miast wschodniego pogranicza Polski swoje peryferyjne, nadgraniczne położenie uważa za możliwość, a nie za barierę rozwoju. Jednak rzadko które miasto analizuje szczegółowo aspekty związane ze swoim położeniem oraz możliwości innowacyjne, które mogłyby wpłynąć na sytuację społeczno-gospodarczą, a zupełnie wyjątkowo rozważany jest wpływ zmian funkcji granic na ich rozwój. Chodzi tu chociażby o wprowadzenie strefy Schengen, oraz o otwieranie bądź zamykanie kolejnych przejść granicznych.

Prezentowane w literaturze wyniki badań w wielu aspektach stawiają miasta nadgraniczne w gorszym świetle, niż pozostałe ośrodki wschodnich województw Polski. Nasuwa się wręcz stwierdzenie, że omawiane tu strategie rozwoju przedstawiają bardziej życzenia władz lokalnych, niż realne plany, bazujące na sytuacji tych peryferyjnie położonych miast. Innym zastanawiającym zjawiskiem występującym w planach i strategiach rozwoju jest pomijanie lub marginalizowanie sprawy, jaką jest peryferyjne, przygraniczne położenie oraz kwestii działań innowacyjnych, zarówno w sferze gospodarczej jak i społecznej. Jak było to już wspomniane, bliskość granicy państwowej w zauważalny sposób wpływa na rozwój i funkcjonowanie miast nadgranicznych, a nieuwzględnianie tego czynnika w planowaniu długofalowego rozwoju jest zastanawiające.

\section{FundUSZE STRUKTURALNE}

W skali lokalnej jednym z motywów przystąpienia Polski do UE była szansa skorzystania z funduszy pomocowych, dostępnych dla biedniejszych regionów krajów członkowskich. Głównym celem tego programu było podniesienie konkurencyjności regionów oraz przeciwdziałanie marginalizacji niektórych obszarów w taki sposób, aby sprzyjać długofalowemu rozwojowi gospodarczemu kraju oraz integracji z Unią Europejską. Przykładem zauważenia trudnej sytuacji regionu wschodniego i stworzenia podstaw finansowych działań pomocowych jest program Rozwój Polski Wschodniej 2007-2013. Jego głównym celem jest ,przyspieszenie tempa rozwoju społeczno-gospodarczego Polski Wschodniej w zgodzie z zasadą zrównoważonego rozwoju”. Szczegółowe zadania dotyczą:

- stymulowania rozwoju konkurencyjnej gospodarki opartej na wiedzy,

- zwiększenia dostępu do Internetu szerokopasmowego w Polsce Wschodniej,

- rozwoju wybranych funkcji metropolitalnych miast wojewódzkich,

- poprawy dostępności i jakości powiązań komunikacyjnych województw Polski Wschodniej,

- zwiększenia roli zrównoważonej turystyki w gospodarczym rozwoju makroregionu,

- optymalizacji procesu realizacji PO Rozwój Polski Wschodniej (Ministerstwo Rozwoju Regionalnego). 
Tab. 1. Fundusze i programy strukturalne realizowane w latach 2007-2013

\begin{tabular}{|c|c|c|c|c|c|c|c|c|}
\hline \multirow{3}{*}{$\begin{array}{l}\text { Fundusze/programy } \\
\text { realizowane w latach } \\
\text { 2007-2013 }\end{array}$} & \multicolumn{2}{|c|}{$\begin{array}{l}\text { Woj. } \\
\text { warmińsko- } \\
\text {-mazurskie }\end{array}$} & \multicolumn{2}{|c|}{$\begin{array}{c}\text { Woj. } \\
\text { podlaskie }\end{array}$} & \multicolumn{2}{|c|}{ Woj. lubelskie } & \multicolumn{2}{|c|}{$\begin{array}{c}\text { Woj. } \\
\text { podkarpackie }\end{array}$} \\
\hline & $\frac{\Xi}{0}$ & $\begin{array}{l}\text { miasta } \\
\text { nad- } \\
\text { gra- } \\
\text { niczne }\end{array}$ & $\begin{array}{l}\frac{\Xi}{0} \\
\frac{0}{0} \\
\text { o. } \\
0\end{array}$ & $\begin{array}{c}\text { miasta } \\
\text { nadgra- } \\
\text { niczne }\end{array}$ & $\frac{\tilde{0}}{0}$ & $\begin{array}{l}\text { miasta } \\
\text { nadgra- } \\
\text { niczne }\end{array}$ & $\frac{\Xi}{0}$ & $\begin{array}{l}\text { miasta } \\
\text { nadgra- } \\
\text { niczne }\end{array}$ \\
\hline & \multicolumn{8}{|c|}{ Liczba projektów } \\
\hline $\begin{array}{l}\text { Europejski Fundusz } \\
\text { Rozwoju Regionalnego }\end{array}$ & 1805 & 38 & 1040 & 24 & 2138 & 77 & 1996 & 92 \\
\hline w tym: & & & & & & & & \\
\hline Infrastruktura i Środowisko & 41 & 0 & 37 & 2 & 50 & 7 & 48 & 0 \\
\hline Innowacyjna Gospodarka & 130 & 3 & 139 & 2 & 194 & 2 & 434 & 2 \\
\hline Rozwój Polski Wschodniej & 16 & 1 & 16 & 0 & 39 & 2 & 20 & 2 \\
\hline $\begin{array}{l}\text { Europejska Współpraca } \\
\text { Terytorialna }\end{array}$ & 0 & 0 & 0 & 0 & 0 & 0 & 0 & 0 \\
\hline Pomoc Techniczna & 4 & 0 & 4 & 0 & 4 & 0 & 5 & 0 \\
\hline Współpraca Transgraniczna & 8 & 0 & 0 & 0 & 0 & 0 & 19 & 1 \\
\hline $\begin{array}{l}\text { Wojewódzkie Programy } \\
\text { Regionalne }\end{array}$ & 1606 & 34 & 843 & 20 & 1850 & 66 & 1469 & 87 \\
\hline $\begin{array}{l}\text { Europejski Fundusz } \\
\text { Społeczny }\end{array}$ & 1400 & 61 & 1157 & 44 & 2193 & 141 & 1643 & 71 \\
\hline w tym: Kapitał Ludzki & 1400 & 61 & 1157 & 44 & 2193 & 141 & 141 & 71 \\
\hline Fundusz Spójności & 23 & 0 & 15 & 1 & 20 & 5 & 20 & 0 \\
\hline $\begin{array}{l}\text { w tym: Infrastruktura } \\
\text { i Środowisko }\end{array}$ & 23 & 0 & 15 & 1 & 20 & 5 & 20 & 0 \\
\hline
\end{tabular}

Źródło: opracowanie własne na podstawie danych www.mapadotacji.gov.pl

Zarówno w grupie badanych miast nadgranicznych, jak i w całym zbiorze miast tych 4 wschodnich województw były ośrodki, gdzie programy strukturalne nie były realizowane. Było to przede wszystkim spowodowane niepodjęciem starań o nie, co świadczy o niewielkim zaangażowaniu władz lokalnych w zarządzanie własnym miastem. Sytuacja taka wynikać może także z braku świadomości wagi problemów rozwojowych, jak również niewielkich chęci poprawy sytuacji społeczno-gospodarczej ze strony lokalnych władz.

Marginalny udział miast nadgranicznych $\mathrm{w}$ realizacji projektów w porównaniu z pozostałymi świadczy o niskiej innowacyjności ich władz i ich niedostosowaniu się do nowych warunków społeczno-ekonomicznych. Biorąc pod uwagę coraz silniejszą konkurencję 
między miastami oraz wzrastającą mobilność przestrzenną ludności Polski, można mówić nawet o zaprzepaszczeniu pewnej szansy, jaka wraz z funduszami strukturalnymi pojawiła się przed miastami nadgranicznymi. Można było choćby częściowo wyrównać szanse rozwojowe i podnieść atrakcyjność, zarówno dla inwestorów z zewnątrz jak i dla ludności miejscowej. Projekty z zakresu Innowacyjnej Gospodarki pozyskały jedynie Bartoszyce, Gołdap, Hajnówka, Sokółka, Lubaczów, Radymno, Tomaszów Lubelski oraz Włodawa. Mając to na uwadze tym bardziej szkoda, że miasta nadgraniczne nie podjęły większego trudu walki o środki pomocowe mogąc tylko częściowo pokrywać realizację projektów z własnych środków. Mogło się również zdarzyć, iż właśnie przez trudną sytuację gospodarczą ośrodki te nie było stać na partycypowanie w kosztach realizacji projektów. Choć tezy tej nie potwierdza fakt, to właśnie niewielkie miasta wykazały się zaangażowaniem na tym polu.

Tab. 2. Wartość programów strukturalnych realizowanych w miastach nadgranicznych w latach 2007-2013

\begin{tabular}{|c|c|c|c|c|}
\hline \multirow{3}{*}{$\begin{array}{c}\text { Fundusze/programy } \\
\text { realizowane } \\
\text { w latach 2007-2013 }\end{array}$} & \multicolumn{4}{|c|}{ Miasta nadgraniczne } \\
\hline & $\begin{array}{l}\text { Woj. } \\
\text { warmińsko- } \\
\text {-mazurskie }\end{array}$ & $\begin{array}{c}\text { Woj. } \\
\text { podlaskie }\end{array}$ & $\begin{array}{c}\text { Woj. } \\
\text { lubelskie }\end{array}$ & $\begin{array}{c}\text { Woj. } \\
\text { podkarpackie }\end{array}$ \\
\hline & \multicolumn{4}{|c|}{ wartość projektów w zł } \\
\hline $\begin{array}{l}\text { Europejski Fundusz Rozwoju } \\
\text { Regionalnego }\end{array}$ & & & & \\
\hline w tym: Innowacyjna Gospodarka & 746437254 & 6618103 & 5561855 & 213745716 \\
\hline Rozwój Polski Wschodniej & 314193770 & - & 56453197 & 289228880 \\
\hline $\begin{array}{l}\text { Europejski Fundusz Społeczny } \\
\text { w tym: Kapitał Ludzki }\end{array}$ & 75719968 & 46629427 & 156339925 & 102639316 \\
\hline
\end{tabular}

Źródło: opracowanie własne na podstawie danych www.mapadotacji.gov.pl

Porównując wartości pozyskanych projektów strukturalnych przez miasta nadgraniczne na przykładzie programów Innowacyjna Gospodarka i Rozwój Polski Wschodniej można zauważyć, że badane ośrodki w województwie warmińsko-mazurskim wykazały się największym zaangażowaniem. Nieco mniejsze ale również duże kwoty zostały pozyskane przez miasta nadgraniczne województwa podkarpackiego. Najmniejsze kwoty zostały przyznane na realizacje programów w miastach nadgranicznych w województwie podlaskim (tab. 2).

Podsumowując można stwierdzić, że środki przeznaczone na politykę regionalną państwa po wstąpieniu Polski do UE z jednej strony zwiększyły potencjalne możliwości rozwojowe, ale również ukazały zagrożenia jakie mogą się pojawić w sytuacji braku zaangażowania władz oraz społeczności lokalnych w działania innowacyjne, mające na celu rozwój endogenicznych zasobów. 


\section{DZIAŁALNOŚĆ PROFESJONALNA, NAUKOWA I TECHNICZNA}

Istotnym wskaźnikiem innowacyjności mieszkańców badanych ośrodków jest analiza liczby podmiotów gospodarczych zaliczających się do działalności profesjonalnej, naukowej i technicznej, a w szczególności zaangażowanych w badania naukowe i prace rozwojowe (tab. 3). Na tym polu jedynie 6 miast nadgranicznych zaznaczyło swoją inicjatywę i to na bardzo niskim poziomie, bo poza Chełmem ośrodki posiadały tylko po jednej tego typu firmie. Są wśród nich największe spośród badanych miast (nie mniejsze niż ok. 10 tys. mieszkańców). Biorąc pod uwagę fakt, że w wielu aspektach ośrodki nadgraniczne wypadają gorzej od pozostałych miast z przygranicznych województw, tak nikłe zaangażowanie w tego typu działalność budzi niepokój o przyszły rozwój tych miast. Nie wytworzą one bowiem wystarczająco silnego kapitału ludzkiego, ani innowacyjnej bazy badawczo-rozwojowej, które mogłyby w dłuższej perspektywie przynieść wymierne korzyści stymulując rozwój gospodarczy.

Tab.3. Liczba podmiotów gospodarczych wpisanych do rejestru REGON w 2010 r., sekcja M (działalność profesjonalna, naukowa i techniczna), dział 72

(badania naukowe i prace rozwojowe)

\begin{tabular}{|l|c|}
\hline \multirow{2}{*}{\multicolumn{1}{|c|}{ Miasto }} & Sekcja M dział 72 \\
\cline { 2 - 2 } & jed. gosp. \\
\hline Chełm & 4 \\
\hline Tomaszów Lubelski & 1 \\
\hline Ustrzyki Dolne & 1 \\
\hline Lubaczów & 1 \\
\hline Przemyśl & 1 \\
\hline Braniewo & 1 \\
\hline
\end{tabular}

Źródło: Bank Danych Lokalnych GUS

\section{PRASA LOKALNA}

Prasa lokalna jest wskaźnikiem zaangażowania społeczności lokalnych w proces przemian miast. Są to wewnętrzne inicjatywy w miastach, które, jak często jest podkreślane, odbiegają pod względem wskaźników rozwoju gospodarczego od pozostałych ośrodków w swoich województwach. Należy także pamiętać, że są to miasta o silnym odpływie ludności. Dlatego tak ważne są wszelkie działania mające na celu aktywizację społeczności lokalnych i pobudzanie rozwoju kapitału społecznego. Istnieją jednak obszary, gdzie żaden tytuł prasy lokalnej nie jest wydawany - i takie, gdzie ukazuje się po kilka tytułów (tab. 4). Do podstawowych problemów rozwoju prasy lokalnej zalicza się warunki techniczne, niewłaściwe uregulowania prawne i nierzadko konflikty na szczeblach administracyjnych oraz niskie zaangażowanie społeczności lokalnych. 
Tab. 4. Liczba gazet, czasopism, wydawców i redakcji w miastach nadgranicznych wschodniego pogranicza Polski na koniec 2006 i 2010 roku

\begin{tabular}{|c|l|c|c|}
\hline \multirow{2}{*}{ L.p. } & \multirow{2}{*}{ Miasto nadgraniczne } & \multicolumn{2}{|c|}{$\begin{array}{c}\text { Liczba gazet, czasopism, } \\
\text { wydawców i redakcji }\end{array}$} \\
\cline { 3 - 4 } & & 2006 & 2010 \\
\hline 1. & Chełm & 7 & 5 \\
\hline 2. & Hajnówka & 3 & 2 \\
\hline 3. & Przemyśl & 3 & 2 \\
\hline 4. & Bartoszyce & 2 & 1 \\
\hline 5. & Braniewo & 1 & 1 \\
\hline 6. & Gołdap & 1 & 1 \\
\hline 7. & Lubaczów & 1 & 1 \\
\hline 8. & Sejny & 1 & 1 \\
\hline 9. & Węgorzewo & 1 & 1 \\
\hline 10. & Ustrzyki Dolne & 1 & 0 \\
\hline 11. & Tomaszów Lubelski & 1 & 0 \\
\hline
\end{tabular}

Źródło: Opracowanie własne na podstawie Polskich Książek Telefonicznych i Panoramy Firm

Podobnie jak w kwestii funduszy pomocowych UE, znów widać niewielkie zaangażowanie badanych miast w tej dziedzinie. Tylko w 9 miastach nadgranicznych wychodzą obecnie gazety, czasopisma, lub istnieją siedziby wydawnictw i redakcje. Są to oczywiście miasta największe spośród analizowanych, czyli Chełm i Przemyśl, ale także miasteczka niewielkie jak np. Sejny. W większości jednak aktywność w tej dziedzinie przejawiają miasta powyżej 10 tys. mieszkańców, położone blisko przejść granicznych. W większości miast, które były omawiane przy wcześniej analizowanych funduszach strukturalnych odnotowano również redakcje gazet i wydawców prasy lokalnej. Wyłania się więc grupa ośrodków nadgranicznych, które w aktywny i świadomy sposób starają się uczestniczyć w zmieniającej się sytuacji społeczno-gospodarczej. Nie zauważono jednak w tym zakresie działań o charakterze innowacyjnym.

\section{FundACJE I STOWARZYSZENIA}

Kolejną formą działalności, dzięki której lokalne społeczności mogą w aktywny sposób uczestniczyć w życiu społecznym, mogąc zmieniać zarówno wizerunek swoich miast jak i (choć w małej skali) swą sytuację ekonomiczną - są fundacje, stowarzyszenia i organizacje społeczne. 
Autorka zbadała liczbę fundacji, stowarzyszeń i organizacji społecznych na 1000 mieszkańców w miastach nadgranicznych wschodniego pogranicza Polski i porównała te wielkości do analogicznych wartości dla wszystkich miast wschodnich województw Polski. W całym okresie badań (1995-2010) zaobserwowano ciągły wzrost tych liczb w obu badanych grupach miast, przy czym wartości te były zbliżone.

Zaobserwowany wzrost liczby fundacji (oraz stowarzyszeń i organizacji społecznych) nie był związany z wielkością miasta nadgranicznego, ani też jego położeniem względem przejścia granicznego, czego dobrym przykładem jest chociażby Węgorzewo. Można więc stwierdzić, że to właśnie zaangażowanie lokalnych społeczności przyczyniło się do takiej sytuacji. Nie bez znaczenia jest większa różnorodność kulturowa i etniczna tych ośrodków i ich zaplecza. Społeczności takie właśnie poprzez zakładanie stowarzyszeń i organizacji społecznych chcą podtrzymać swe tradycje i kulturę, jak również zaznaczyć swoją obecność. Innym powodem mogą być starania w kierunku przezwyciężenia różnego typu problemów społecznych czy gospodarczych, z jakimi społeczności te się borykają, co w tym przypadku można zaliczyć do działań innowacyjnych. Motywy mogą również wynikać z silnie wykształconej funkcji turystycznej, która także sprzyja powstawaniu różnego typu organizacji (Zdon-Korzeniowska 2009).

Tab. 5. Dynamika zmian przyrostu liczby fundacji oraz stowarzyszeń i organizacji społecznych zarejestrowanych w miastach nadgranicznych w latach 1995-2010 w badanych miastach nadgranicznych

\begin{tabular}{|c|l|c|c|c|}
\hline \multirow{2}{*}{ L.p. } & \multirow{2}{*}{ Miasta nadgraniczne } & \multicolumn{2}{|c|}{$\begin{array}{c}\text { Podmioty gospodarki zarejestrowane } \\
\text { w rejestrze REGON w sektorze prywatnym }\end{array}$} \\
\cline { 3 - 5 } & & Fundacje & \multicolumn{3}{|c|}{$\begin{array}{c}\text { Stowarzyszenia } \\
\text { i organizacje społeczne }\end{array}$} \\
\cline { 3 - 5 } & & \multicolumn{2}{|c|}{$1995=100$} & $\begin{array}{c}\text { na 1000 mieszkańców } \\
(2010 \text { r.) }\end{array}$ \\
\cline { 3 - 5 } & & 200 & 775 & 2,51 \\
\hline 1 & Bartoszyce & 300 & 1333 & 2,29 \\
\hline 2 & Braniewo & 233 & 550 & 2,45 \\
\hline 3 & Chełm & 0 & 1300 & 6,69 \\
\hline 4 & Cieszanów & 100 & 1000 & 2,02 \\
\hline 5 & Dąbrowa Białostocka & 200 & 366 & 4,54 \\
\hline 6 & Frombork & - & - & 2,98 \\
\hline 7 & Gołdap & 100 & 1200 & 2,72 \\
\hline 8 & Górowo Iławeckie & 300 & 920 & 2,15 \\
\hline 9 & Hajnówka & 200 & 1050 & 2,29 \\
\hline 10 & Hrubieszów & 0 & 500 & 3,60 \\
\hline 11 & Kleszczele & 0 & 800 & 1,80 \\
\hline 12 & Korsze & 0 & 800 & 1,40 \\
\hline 13 & Lipsk & & 2450 & 3,96 \\
\hline 14 & Lubaczów & & \\
\hline & & & & \\
\hline
\end{tabular}




\begin{tabular}{|r|l|r|r|r|}
\hline 15 & Narol & \multicolumn{1}{|c|}{-} & \multicolumn{1}{c|}{-} & 2,90 \\
\hline 16 & Oleszyce & 0 & 800 & 2,64 \\
\hline 17 & Pieniężno & 100 & 1000 & 5,36 \\
\hline 18 & Przemyśl & 233 & 369 & 3,96 \\
\hline 19 & Radymno & 100 & 700 & 1,29 \\
\hline 20 & Sejny & 200 & 560 & 4,91 \\
\hline 21 & Sępopol & 0 & 600 & 2,98 \\
\hline 22 & Sokółka & 100 & 1600 & 2,59 \\
\hline 23 & Terespol & 100 & 800 & 1,36 \\
\hline 24 & Tomaszów Lubelski & 100 & 677 & 3,08 \\
\hline 25 & Tyszowce & - & & 3,30 \\
\hline 26 & Ustrzyki Dolne & 400 & 513 & 4,39 \\
\hline 27 & Węgorzewo & 700 & 2600 & 4,57 \\
\hline 28 & Włodawa & 200 & 740 & 2,76 \\
\hline
\end{tabular}

,-" oznacza brak danych dla roku 1995

Źródło: Opracowanie własne na podstawie danych Banku Danych Regionalnych GUS

Z powyższej tabeli wynika generalny brak zależności badanego wskaźnika od poziomu zaludnienia miast nadgranicznych, wyraźne znaczenie miało jednak położenie tych ośrodków względem poszczególnych odcinków granic.

\section{MEDIA}

Od połowy lat 90. ubiegłego stulecia obserwuje się dynamiczny wzrost znaczenia Internetu zarówno w życiu poszczególnych ludzi, społeczności, jak i funkcjonowaniu samorządów na różnym szczeblu organizacji. Wzrasta też znaczenie wiedzy i informacji jako czynników długookresowego rozwoju i konkurencyjności (Dahlman 2002). Coraz większą popularność zyskuje koncepcja budowy społeczeństwa informacyjnego (SI) jako jednego z priorytetów UE, realizowanego jako eEurope (European Commision 2000). Wkrótce po tym podobne programy przyjęły państwa członkowskie UE i państwa kandydujące, w tym Polska: ePolska - Plan działań na rzecz rozwoju społeczeństwa informacyjnego w Polsce na lata 2001-2006 (Ministerstwo Gospodarki 2001) (w: Guzik 2004).

Nowoczesne technologie przepływu informacji, w tym Internet, uważane były w latach 90. za innowacyjny przełom w dalszym rozwoju małych i peryferyjnie położonych regionów i miejscowości (Harris 1998). Niestety, badania nie potwierdziły tej tezy, a rozwój Internetu odzwierciedla koncentrację gospodarki informacyjnej w dużych ośrodkach miejskich (Guzik 2004). To właśnie one, skupiając kreatywność i innowacyjność, stają się obecnie głównymi źródłami produktywności - mając o wiele większą przewagę konkurencyjną niż kiedykolwiek wcześniej (Castells 2003). Właśnie ze względu na coraz silniejszą konkurencję między 
miastami, małe i peryferyjnie położone powinny dążyć do wdrożenia nowoczesnych technologii przepływu informacji. Badania geografii Internetu mogą zaoferować wiele wskaźników przydatnych do innych studiów, na przykład nad zróżnicowaniami w poziomie życia czy konkurencyjności (Guzik 2004).

Celem poznania otwartości władz i mieszkańców miast nadgranicznych wschodniego pogranicza Polski na nowoczesne technologie przepływu informacji autorka zbadała następujące kwestie:

- posiadanie oficjalnych stron internetowych,

- możliwość kontaktu on-line z burmistrzem/prezydentem miasta za pośrednictwem poczty elektronicznej,

- przynależność miasta do Związku Miast Polskich,

- liczbę miast partnerskich,

- miejsce w Rankingu Gmin i Powiatów w 2007 r.,

- liczbę stron www, gdzie w tytule pojawiła się nazwa miasta (w wartościach bezwzględnych jak i w przeliczeniu na 1000 mieszkańców).

Z przeprowadzonych badań wynika, że wszystkie miasta nadgraniczne posiadają strony internetowe, lecz informacje jakie są tam zamieszczone oraz ich jakość są zróżnicowane. Częstym przypadkiem jest posiadanie jednej strony internetowej dla miasta i gminy, zwłaszcza w przypadku miast o statucie gminy miejsko-wiejskiej. Prawie wszystkie badane ośrodki (z wyjątkiem Ustrzyk Dolnych) posiadają strony Biuletynu Informacji Publicznej (BIP). Dzięki zawartym tam informacjom w szybszy i sprawniejszy sposób można uzyskać pożądane informacje dotyczące funkcjonowania m.in. administracji publicznej.

Miastem nadgranicznym, które najpełniej realizuje postulat powszechnego udostępniania informacji publicznej jest Chełm z 39 stronami BIP. Należy pamiętać, iż jest to największe $\mathrm{z}$ analizowanych miast, które przez 23 lata pełniło obowiązki stolicy województwa, a to wiązało się z rozwinięciem wielu funkcji administracyjnych. Porównując jednak Chełm z podobnym wielkościowo Przemyślem, który także był stolicą województwa w latach 19751998, widzimy bardzo dużą różnicę, gdyż Przemyśl przygotował jedynie 13 stron BIP.

Wychodząc z założenia, że Internet może stać się także kanałem kontaktu władzy z obywatelami, duży nacisk kładziony jest obecnie na realizację idei ,przyjaznej” i efektywnej administracji publicznej. Przejawem tak rozumianej administracji jest stworzenie możliwości kontaktu obywateli z przedstawicielami władz przy użyciu poczty elektronicznej. Niestety ,[...] mimo istnienia odpowiedniej infrastruktury technicznej, realizacja koncepcji e-government w Polsce jest daleka od stanu pożądanego" (Gazeta IT 2003). Badania takie dowodzą, na ile władze lokalne są otwarte na nowe formy kontaktu z mieszkańcami, oraz na ile są w stanie tworzyć przyjazny wizerunek władzy i dążą do sprawnego działania urzędów.

Przeprowadzone badania wykazały, że w ok. 46\% miast nadgranicznych istnieje potencjalna możliwość kontaktu z burmistrzem/prezydentem za pośrednictwem poczty elektronicznej. Jest to wynik niższy od średniej, jaka została wyliczona dla Polski (Guzik 2004).

Jednym z wyznaczników innowacyjności władz lokalnych i chęci poprawy zarówno sytuacji gospodarczej jak i społecznej w swoich jednostkach administracyjnych jest przynależność do różnego typu organizacji oraz stowarzyszeń, które mogą pełnić funkcje doradcze lub inicjować jakieś działania. Przykładem takiej organizacji jest Związek Miast Polskich (ZMP). Głównym jego celem jest wspieranie działalności miast i gmin (http://www.miasta-polskie.pl). 
Przeprowadzone analizy wykazały, że tylko 6 z 28 badanych miast nadgranicznych (21\%) należy do Związku Miast Polskich. Większość z nich to małe miasta (5-10 tys. mieszkańców), nie ma tam jednak miast najmniejszych. Z 6 miast 5 leży przy granicach z Obwodem Kaliningradzkim i Ukrainą, a jedno (Sokółka) przy granicy z Białorusią. Tak niski udział miast nadgranicznych w ZMP nie jest korzystny dla ich rozwoju, świadczy też o niewielkich staraniach władz lokalnych w szukaniu pomocy czy wsparcia „z zewnątrz”.

Kolejną formą otwartości miast (a szczególnie ich władz) na inne ośrodki są umowy współpracy z miastami partnerskimi. Przeprowadzone badania wykazały, że niespełna 54\% miast nadgranicznych podpisało umowy z miastami partnerskimi. Najwięcej partnerów posiada Przemyśl (8).

Starania jakie lokalne władze wykazują w kierunku zaistnienia ich miasta (nie tylko na poziomie lokalnym) oraz w zakresie podnoszenia warunków życia mieszkańców i współpracy z innymi ośrodkami, są oceniane w różnego typu rankingach. Przykładem może być Ranking Gmin i Powiatów w 2007 r., przygotowany przez Związek Powiatów Polskich. Punkty były przyznawane za: promocję jednostki w Internecie, przekazywanie różnorodnych treści (także w obcym języku), wspieranie rozwoju społeczeństwa informacyjnego (w tym posiadanie Biuletynu Informacji Publicznej) oraz za jakość obsługi mieszkańców (w tym posiadanie różnego typu certyfikatów) jak również za rozwój informacyjny miasta (www.gminypolskie.pl). Część miast uzyskała te same miejsca w rankingu, oferując swoim mieszkańcom porównywalne udogodnienia. Najwyższe miejsce spośród badanych ośrodków uzyskał Przemyśl plasując się na 33 miejscu w Polsce. Kolejną pozycję zajęły Bartoszyce zajmując 87 miejsce. Najwięcej miast nadgranicznych uplasowało się pomiędzy 225 a 234 miejscem w Rankingu. Wynika z tego, że ośrodki nadgraniczne w porównaniu z innymi miastami w Polsce wykazują niewielkie starania w kierunku innowacyjności działania władzy i społeczeństwa informacyjnego. Ta generalna tendencja nie będzie sprzyjać dynamicznemu przyszłemu rozwojowi tychże jednostek.

Jako miernik aktywności władz lokalnych (choć przede wszystkim chyba mieszkańców) oraz chęci promocji swojego miasta autorka uznała liczbę stron www, w których tytule pojawia się jego nazwa. Duża liczba stron internetowych to z jednej strony chęć zaistnienia, reklamy, jak również łatwiejszy sposób pozyskania informacji o mieście przez osoby „,z zewnątrz”, pragnące dowiedzieć się czegoś o nim, odwiedzić je czy nawet w nim zainwestować. Autorka ma świadomość faktu, że nie wszystkie strony internetowe w których nazwie pojawia się nazwa badanego miasta są stworzone przez mieszkańców bądź władze tej jednostki, przez co wyniki takiego badania mogą być obarczone pewnym błędem. Dlatego właśnie taka analiza będzie jedynie służyć celom porównawczym.

Wyniki badań w wartościach bezwzględnych pokazują silną zależność od wielkości miasta nadgranicznego. Jednak po przeliczeniu otrzymanych wyników na 1000 mieszkańców zauważamy, że najmniejsze ośrodki uzyskały bardzo wysokie wartości. 
Tab. 6. Miasta nadgraniczne on-line wg liczby stron www, gdzie w tytule pojawiła się nazwa miasta

\begin{tabular}{|c|c|c|c|c|c|c|c|c|}
\hline \multirow[b]{2}{*}{ L.p. } & \multirow[b]{2}{*}{ 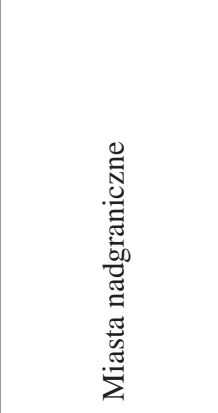 } & \multirow[b]{2}{*}{ 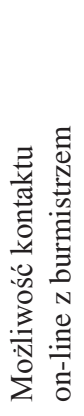 } & \multirow[b]{2}{*}{ 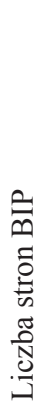 } & \multirow[b]{2}{*}{ 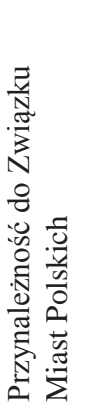 } & \multirow[b]{2}{*}{ 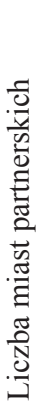 } & \multirow{2}{*}{ 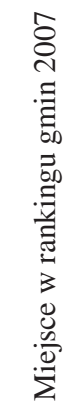 } & \multicolumn{2}{|c|}{$\begin{array}{c}\text { Liczba stron www gdzie } \\
\text { w tytule pojawia się nazwa miasta }\end{array}$} \\
\hline & & & & & & & $\begin{array}{c}\text { wartość } \\
\text { bezwzględna } \\
\text { (w tys.) }\end{array}$ & $\begin{array}{c}\text { na } 1000 \\
\text { mieszkańców }\end{array}$ \\
\hline 1. & Chełm & + & 39 & - & 5 & - & 28500 & 423326 \\
\hline 2. & Gołdap & + & 13 & + & 5 & 228 & 25800 & 1925229 \\
\hline 3. & Bartoszyce & + & 9 & + & 4 & 87 & 17700 & 715990 \\
\hline 4. & Cieszanów & + & 3 & - & 5 & 173 & 14000 & 7205353 \\
\hline 5. & $\begin{array}{l}\text { Tomaszów } \\
\text { Lubelski }\end{array}$ & - & 8 & - & 1 & 138 & 10600 & 535299 \\
\hline 6. & Sokółka & + & 6 & + & 1 & 233 & 10400 & 561191 \\
\hline 7. & Hrubieszów & - & 8 & - & - & 228 & 10100 & 551370 \\
\hline 8. & Ustrzyki Dolne & - & 0 & - & 1 & 189 & 10100 & 1080329 \\
\hline 9. & Węgorzewo & + & 5 & - & 4 & 229 & 9350 & 821834 \\
\hline 10. & Lubaczów & + & 5 & + & 3 & 198 & 8530 & 689349 \\
\hline 11. & $\begin{array}{l}\text { Dąbrowa } \\
\text { Białostocka }\end{array}$ & - & 1 & - & 2 & 232 & 8060 & 1359649 \\
\hline 12. & Przemyśl & + & 13 & + & 8 & 33 & 7920 & 119585 \\
\hline 13. & Sejny & - & 4 & - & 1 & 172 & 5710 & 1000526 \\
\hline 14. & Hajnówka & - & 5 & - & - & 225 & 5540 & 258347 \\
\hline 15. & Włodawa & + & 7 & - & - & 155 & 4550 & 339502 \\
\hline 16. & Frombork & + & 1 & - & 1 & 198 & 4230 & 1744330 \\
\hline 17. & Terespol & + & 1 & - & - & 234 & 3830 & 649043 \\
\hline 18. & Narol & + & 1 & - & - & 231 & 2530 & 1222813 \\
\hline 19. & Radymno & - & 2 & - & - & 233 & 2200 & 404412 \\
\hline 20. & $\begin{array}{l}\text { Górowo } \\
\text { Iławeckie }\end{array}$ & - & 2 & - & 3 & 232 & 2130 & 482010 \\
\hline 21. & Lipsk & - & 4 & - & - & 229 & 2080 & 364784 \\
\hline 22. & Pieniężno & - & 1 & - & 2 & 172 & 1950 & 696180 \\
\hline 23. & Oleszyce & + & 1 & - & - & 233 & 1860 & 612648 \\
\hline 24. & Sępopol & + & 1 & - & - & 165 & 1760 & 874317 \\
\hline 25. & Braniewo & + & 15 & + & 2 & 232 & 1710 & 97955 \\
\hline
\end{tabular}




\begin{tabular}{|l|l|r|r|r|r|r|r|r|}
\hline 26. & Korsze & - & 2 & - & - & 165 & 1090 & 245054 \\
\hline 27. & Tyszowce & + & 1 & - & - & 228 & 1020 & 480452 \\
\hline 28. & Kleszczele & - & 1 & - & - & 232 & 865 & 623199 \\
\hline
\end{tabular}

Źródło: Opracowanie własne w oparciu o informacje ze stron internetowych miast nadgranicznych www.miasta-polskie.pl, www.gminypolskie.pl oraz wyszukiwarki www.google.pl

\section{ZAKOŃCZENIE}

Endogeniczna działalność w miastach nadgranicznych mogłaby dynamizować ich rozwój, zwłaszcza gdyby wiązała się z działaniami innowacyjnymi. Niestety w dużej części tych ośrodków nie jest ona aktywnie rozwijana ani przez mieszkańców, ani władze lokalne. Zdecydowana większość badanych ośrodków ma opracowane strategie rozwoju lub plany rozwoju lokalnego, lecz nie zawsze opisują one w rzetelny sposób sytuację miast. Jak wykazały badania, granica państwa ma silny, negatywny wpływ na rozwój znajdujących się w jej pobliżu ośrodków. Niestety nie wszystkie $\mathrm{z}$ badanych miast w strategiach rozwoju podkreślają swoje położenie jako czynnik oddziałujący na ich rozwój, jednocześnie nie proponując zastosowania wiedzy oraz szybkiego i sprawnego przesyłania informacji. Nie zaznacza się również umiejętność przekształcania istniejących możliwości w nowe idee i wprowadzania ich do praktycznego zastosowania. Jednocześnie duża część ośrodków postrzega pobliską granicę w charakterze szans rozwoju, co bez zgłoszenia pewnych zastrzeżeń i zwrócenia uwagi na lokalne uwarunkowania jest według autorki nieadekwatne do panującej tam sytuacji społeczno-gospodarczej i świadczy o bagatelizowaniu przez lokalne władze problemów gospodarczych i demograficznych. Potwierdzeniem niewielkich starań władz lokalnych na rzecz zmiany sytuacji w miastach nadgranicznych są mniejszy odsetek ośrodków, które otrzymały fundusze pomocowe w stosunku do ogółu miast we wschodnich województwach Polski oraz pojedyncze podmioty zajmujące się działalnością badawczo-rozwojową. Bardzo zróżnicowany obraz miast nadgranicznych ukazują badania odnoszące się do rozwoju społeczeństwa informacyjnego i wykorzystania Internetu zarówno przez mieszkańców, jak i władze lokalne.

Wobec takiego obrazu endogenicznej działalności miast wschodniego pogranicza Polski zasadne wydaje się dalsze poszukiwanie bądź nakłanianie do działań o charakterze innowacyjnym mogących zdynamizować rozwój badanych ośrodków. Borykają się one bowiem z poważnymi trudnościami demograficznymi pozostając jednocześnie na gospodarczych peryferiach państwa.

\section{Literatura}

Brzosko-Sermak A., 2009, Szczególne cechy rozwoju miast wschodniego pogranicza Polski, [w:] Z. Górka, A. Zborowski (red.), Człowiek i rolnictwo, IGiGP UJ, Kraków, s. 203-212.

Borowiec M., Dorocki S., Jenner B., 2009, Wpływ zasobów kapitału ludzkiego na kształtowanie społeczeństwa informacyjnego i innowacyjności struktur przemysłowych, Prace Komisji Geografii Przemysłu, Nr 13, Warszawa-Kraków, s. 95-109. 
Castells M., 2003, Galaktyka Internetu. Refleksje nad Internetem, biznesem i społeczeństwem, Dom Wydawniczy Rebis, Poznań.

Chojnicki Z., 1999, Podstawy metodologiczne i teoretyczne geografii, Bogucki Wydawnictwo Naukowe, Poznań.

Chojnicki Z., 2007, Rola kapitału ludzkiego w ksztattowaniu gospodarki opartej na wiedzy w Polsce, Przegląd Geograficzny 3-4, s. 423-438.

Churski P., Krawczyk P., Tobolska A., 1994, Poziom bezrobocia a aktywność gospodarcza na obszarze wschodniego pogranicza Polski, [w:] T. Wilgat (red.), Ogólnopolski Zjazd Polskiego Towarzystwa Geograficznego, Referaty i postery, Polskie Towarzystwo Geograficzne Oddział Lubelski, Uniwersytet Marii Curie-Skłodowskiej, Lublin.

Ciok S., Dobrowolska-Kaniewska H., 2009, Polityka innowacyjna państwa a regionalny potencjal innowacyjny. Przykład Dolnego Ślaska, Rozprawy Naukowe Instytutu Geografii i Rozwoju Regionalnego Uniwersytetu Wrocławskiego 7, Instytutu Geografii i Rozwoju Regionalnego Uniwersytetu Wrocławskiego, Wrocław, s. 9.

Dahlman C., 2002, The Knowledge Economy: Implications for Poland, World Bank Institute.

Dziewoński K., 1971, Baza ekonomiczna i struktura funkcjonalna miast. Studium rozwoju pojęć, metod i ich zastosowań, Prace Geograficzne IG PAN, s. 87.

Eberhardt P., 2004, Polska i jej granice. Z historii polskiej geografii politycznej, Wydawnictwo UMCS, Lublin.

European Commision, 2000, eEurope - An Information Society for All, Brussels.

Gazeta IT nr 3 (11) marzec 2003.

Guzik R., 2004, Polskie miasta i gminy wiejskie w Internecie - geografia społeczeństwa informacyjnego, [w:] J. Słodczyk (red.), Rozwój miast i zarządzanie gospodarką miejską, Miasta w okresie przemian, Opole.

Hansen N., 2001, The Economic Development of Border Regions, Knox, Marston 1998.

Komornicki T., 1999, Granice Polski, Analiza zmian przenikalności w latach 1990-1996, Geopolitical Studies, vol. 5, IGiGP PAN, Warszawa.

Komornicki T., 2003, Przestrzenne zróżnicowanie międzynarodowych powiązań społeczno-gospodarczych $w$ Polsce, Prace Geograficzne Nr 190, IGiGP PAN, Warszawa.

Koter M., 1998, Multicultural Border Regions of Europe - Forms of Ethnic Composition and Process of their Differentiation, [w:] K. Heffner, M. Koter (red.), Borderlands or transborder regions.

Krzysztofik R., 2000, Umiastowienie pótnocno-wschodniej Polski w świetle wybranych pojęć i teorii z zakresu geografii społeczno-ekonomicznej, Czasopismo Geograficzne LXXI, 2, s. 189-208.

Lijewski T., 1994, Problemy komunikacyjne wschodniego pogranicza Polski, [w:] T. Wilgat (red.), Ogólnopolski Zjazd Polskiego Towarzystwa Geograficznego, Referaty i postery, Polskie Towarzystwo Geograficzne Oddział Lubelski, Uniwersytet Marii Curie-Skłodowskiej, Lublin.

Minghi J.V., 1963, Boundary studies in political geography, Annals of the Association of American Geographers, 53, s. 407-428.

Ministerstwo Rozwoju Regionalnego, 2007, Program Operacyjny Rozwój Polski Wschodniej 20072013, Narodowe Strategiczne Ramy Odniesienia 2007-2013, Projekt nr 6, Warszawa.

Misztal S., 1994, Zacofanie i perspektywy rozwoju regionów przygranicznych wschodniej Polski, [w:] T. Wilgat (red.), Ogólnopolski Zjazd Polskiego Towarzystwa Geograficznego, Referaty i postery, Polskie Towarzystwo Geograficzne Oddział Lubelski, Uniwersytet Marii Curie-Skłodowskiej, Lublin.

Osborn D., Gaebler T., 1992, Reinventing Government. How the entrepreneurial spirit is transforming the public sector, Addisin-Wesley, Boston.

Passi A., 2001, „A Borderless world“-Is it only rhetoric or will boundaries disappear in the globalizing world?, [w:] P. Reubner, G. Wolkersdorfer (red.), Politische Geographie: Handlungsorientierte 
Ansätze und Critical Geopolitics, Heidelberger Geographische Arbeiten, Heft 112, Im Selbstverlag des Geographischen Instituts der Universität Heidelberg, Heidelberg, s. 133-145.

Proniewski M., 1993, Główne problemy rozwoju wschodniego obszaru pogranicza, [w:] P. Eberhardt, T. Komornicki (red.), Problematyka wschodniego obszaru pogranicza, Biuletyn nr 2, IGiPZ PAN, Warszawa.

Rachwał T., Wiedermann K., Kilar W., 2009, Rola przemystu $w$ gospodarce układów regionalnych Unii Europejskiej, Prace Komisji Geografii Przemysłu, Nr 14, Warszawa-Kraków, s. 31-42.

Rzeszowska Agencja Rozwoju Regionalnego, 2000, Strategia Rozwoju Miasta Radymno, Rzeszów.

Sobala-Gwosdz A., 2005, Ośrodki wzrostu i obszary stagnacji w województwie podkarpackim, Instytut Geografii i Gospodarki Przestrzennej UJ, Kraków.

Ustawa z dnia 12 października 1990 r. o ochronie granicy państwowej (Dz. U. Nr 78, poz. 461, z późn. $\mathrm{zm}$.)

Zdon-Korzeniowska M., 2009, Jak ksztaltować regionalne produkty turystyczne, Wydawnictwo Uniwersytetu Jagiellońskiego, Kraków.

Zioło Z., 2010, Procesy innowacyjności przestrzeni społeczno-gospodarczej, [w:] S. Ciok, P. Migoń (red.), Przekształcenia struktur regionalnych. Aspekty społeczne, ekonomiczne i przyrodnicze, Instytut Geografii i Rozwoju Regionalnego, s. 185-201.

\section{Adresy internetowe}

http://www.miasta-polskie.pl

http://www.miasta-polskie.pl

http://www.gminypolskie.pl

http://www.senat.gov.pl

\section{Innovation and the endogenous resources of Polish eastern border cities}

The interest in the Polish eastern border cities is rooted in the desire to trace their socio-economic and urban development conditions of a specific, peripheral location within the provinces which are facing many problems. The general study covers four eastern Polish provinces; detailed investigations were carried out in 28 border cities located within those areas. It seems interesting to examine the involvement of the local authorities and citizens in different types of initiatives that encourage internal development. For this reason, the main objective of this study was to investigate selected aspects of endogenous activities and consider whether one can allocate them as an innovation, and whether they can condition the local success or stagnation. Analysis of the activity of the local authorities was based on urban development strategies and EU structural funds. Analysis of the activity of the local community was based on: the professional, scientific and technical activities; local newspapers, publishers and editors; and foundations and community organizations.

Endogenous activity in the border cities could step up their development especially if associated with innovation activities. Unfortunately, large part of these cities is not developed in an active way, neither by residents nor local authorities.

Dr Agnieszka Brzosko-Sermak

Uniwersytet Pedagogiczny, Kraków

Instytut Geografii

Zakład Przedsiębiorczości i Gospodarki Przestrzennej

e-mail: abrzosko@up.krakow.pl 